UDC 539.43: 621.64

O. Stanovskiy, DSc, Prof.,

I. Prokopovitch, DSc, Assos. Prof.,

H. Olekh,

K. Kolesnikova, DSc, Prof.,

L. Sorokina

Odessa National Polytechnic University, 1 Shevchenko Ave., Odessa, Ukraine, 65044; e-mail: igor.prokopovich@gmail.com

\title{
PROCEDURE FOR IMPACT ASSESSING ON THE ENVIRONMENT
}

О.Л. Становський, І.В. Прокопович, Г.С. Олех, К.В. Колеснікова, Л.І. Сорокіна. Процедура оцінки впливу на навколишнє середовище. Сьогодні у всьому світі велика увага приділяється екології та дотримання природоохоронних норм. Будь-яка людська діяльність повинна надавати мінімальний вплив на навколишнє середовище, і зараз це ні в кого не викликає сумнівів. Для визначення ступеня впливу існує екологічна експертиза - комплекс заходів, покликаних підтвердити безпеку об'єктів і виробничих процесів. Екологічну експертизу можна розглядати як «превентивний контроль», тобто процедуру, що запобігає інвестуванню та реалізації свідомо шкідливих для навколишнього середовища проектів. У статті зроблена спроба гармонізувати підходи до оцінки впливу на навколишнє середовище, що існують в національній та світовій практиці. Наведені методологічні аспекти оцінки впливу базуються на визначенні трьох параметрів: просторового масштабу впливу; тимчасового масштабу вплив та інтенсивності впливу. Кожен з параметрів оцінюється за певною шкалою, із застосуванням відповідних критеріїв, розроблених та поданих для кожної градації шкали. Напівкількісний метод оцінки впливу, описаний в даній статті, грунтується на експертній оцінці фахівців різних компаній України і працівників науково-дослідних установ.

Ключові слова: вплив на навколишнє середовище, проект, екологічна експертиза, функція Харрінгтона, масштаб впливу, шкала оцінки, критерії значимості

O. Stanovskiy, I. Prokopovitch, H. Olekh, K. Kolesnikova, L. Sorokina. Procedure for impact assessing on the environment. Today, around the world, much attention is paid to ecology and compliance with environmental standards. Any human activity should have minimal impact on the environment, and now it's no one's doubts. To determine the degree of influence, there is an environmental assessment - a set of measures designed to confirm the safety of facilities and production processes. Environmental expertise can be considered as a "preventive control", that is, a procedure that prevents investment and the realization of projects that are detrimental to the environment. This article attempts to harmonize the approaches to the impact assessment on environment available in national and world practice. The presented methodological aspects of impact assessment are based on the definition of following three parameters: the spatial scale of influence; the temporary scale of influence; the intensity of influence. Each of the parameters is evaluated on a certain scale, using the relevant criteria developed and presented for each grading scale. The semi-quantitative impact assessment method described in this article is based on an expert evaluation of specialists from different companies in Ukraine and employees of research institutions.

Keywords: impact assessing on the environment, project, environmental expertise, Harrington function, impact scale, scale of assessment, significance criteria

Introduction. The procedure of impact assessing on the environment, in this case considered and determined in accordance with the requirements of the Law of Ukraine "About Environmental Expertise" (Resolution of the Verkhovna Rada No. 46/95-VR of February 9, 1995, VVR, 1995, No. 8, p.55) [1]

This article examines the methodological approaches of the impact assessment on the natural environment, considers the structure, content and procedure of "Impact assessment of planned activities on the environment" in the regular situation.

The section "Impact Assessment on Environment" (EIA) is a necessary component of a complete environmental assessment. The impact assessment of the planned activity on the natural environment is carried out with the use of available materials and statistical data provided by the territorial departments of the Ministry of Ecology and Natural Resources of Ukraine, as well as various scientific and research organizations.

The assessment of possible impact on environment resulting from the implementation of the project is an important stage in the process of EIA $[2,3]$. The purpose of the assessment is to identify the

\section{DOI: 10.15276/opu.1.54.2018.14}

(C) 2018 The Authors. This is an open access article under the CC BY license (http://creativecommons.org/licenses/by/4.0/). 
environmental changes that may occur as a result of the planned activity and to assess the significance of these changes (Fig. 1).

This assessment is based on the following $[4,5]$ :

- technical description of the project;

- defining of environmental components that are exposed;

- the experience gained from other projects.

Impact assessment is carried out according to individual components of the natural environment.

In the performing the usual EIA as the most important ecosystems and components of the environment, we assess the impact on:

- soil and subsoil;

- surface and seawater;

- ground water;

- sea sediments;

- quality air;

- biological resources;

- landscapes and visual effects;

- physical factors of influence (noise and electromagnetic effects, vibration, etc.).

In general, the measures taken to mitigate the impact are set during the development of the project according to the scale presented in Table 1.

Table 1

Scale of impact reducing for activities planned by the project

\begin{tabular}{|c|c|}
\hline Grades of the scale & Structure of measures to reduce and prevent impacts \\
\hline $\begin{array}{l}\text { - prevention of } \\
\text { impact near the } \\
\text { source; } \\
\text { - decrease of impact } \\
\text { on the source }\end{array}$ & $\begin{array}{l}\text { Preventing or reducing the impact near the sources suggested by such design } \\
\text { decisions under which the causes of the impact is excluded or modified. Also, the } \\
\text { term "minimization" is used }\end{array}$ \\
\hline $\begin{array}{l}\text { - reduction of on-site } \\
\text { impact }\end{array}$ & $\begin{array}{l}\text { It is envisaged to apply modifications to the original design development, for } \\
\text { example, measures to control environmental pollution. Often referred to as "on-site } \\
\text { cleaning technology" }\end{array}$ \\
\hline $\begin{array}{l}\text { - impact weakening } \\
\text { outside }\end{array}$ & $\begin{array}{l}\text { If the impact cannot be weakened on the site of the reset, then these measures can be } \\
\text { carried out outside the site of the object }\end{array}$ \\
\hline $\begin{array}{l}\text { - recovery or } \\
\text { correction }\end{array}$ & $\begin{array}{c}\text { Some influences lead to inevitable loss of resources. Recovery involves measures to } \\
\text { return the resource to its original state }\end{array}$ \\
\hline $\begin{array}{l}\text { - compensation for } \\
\text { loss }\end{array}$ & $\begin{array}{l}\text { If other measures to mitigate impacts are not possible or not sufficiently effective, } \\
\text { compensation for losses and general intrusion is acceptable. Compensation may be } \\
\text { "natural", which is expressed, for example, in planting new plantations instead of lost } \\
\text { ones }\end{array}$ \\
\hline
\end{tabular}

The aim of the paper is harmonization of the approaches to environmental impact assessment that are used in the national and world practice.

Materials and methods. Assessment of impact. The study of the impacts includes measures toward impact mitigation that already provided by the project on the basis of the works, which are included in the previous design. In assessing the impact we study the residual effects, that is, those effects that remained after the application of mitigation measures [6].

EIA reflects the state of the project, based on available pre-design information. The working project will be conducted to further elaborate many measures toward impact mitigation. However, the characteristics of the environment have been established at the stage of preliminary design. 
For many influences, the assessment of the significance of the residual impact is based on the characteristics given in the previous design. These commitments will be made by contractors and detailed for further implementation. This will ensure that mitigation measures that have been applied at least once will exert an impact that will not be more ecologically than the effects of the EIA.

The significance or degree of residual impacts in this EIA will not necessarily be the same as those already described in the project, as further impact mitigation will be studied for many types of impacts at the stage of the work project. The actual actions from the final project are expected to be no more than those already described [7].

Criteria of significance. Significance of residual effects is estimated based on:

- possibilities of influence;

- consequence of influence.

Evaluation takes place on a local, limited, local and regional impact levels. Particular attention in impacts assessing is given to local and limited levels of influence. Similar attention is paid to vulnerable resources (for example, species listed in the Red Book).

In the most assessments of impacts on the natural environment it is difficult to quantify the ecological changes. The proposed methodology is a semi-quantitative assessment based on the so-called "curve of desirability", as well as interval scales.

The significance of anthropogenic environmental violations at all levels is estimated by the following parameters:

- Spatial scale;

- Time scale;

- Intensity.

We investigate these parameters using one of the Harrington logistic functions "curve of desirability" [8]. It is defined by the function $d=\exp (-\exp (-Y))$. This function is empirically derived. The axis of coordinate $Y$ is called the scale of partial indicators. The $d$ axis is scale of desirability.

The interval of effective values on the scale of partial indicators is $[-2 ; 5]$. The desirable scale divides in the range from 0 to 1 in five intervals, each of which is determined by experts in the fuzzy expression: [0;0.2] - "very bad", [0.2, 0.37] - "bad", [0.37;0.63] - "satisfactorily", [0.63;0.8] "good", $[0.8 ; 1]$ - "very good". For ease of computation, we combine the last two spaces into one and give it an unclear expression $[0.63 ; 1]$ - "good".

The choice of marks on the scale of desirability -0.63 and 0.37 , due to the convenience of calculations: $1-\frac{1}{e} \approx 0.63, \frac{1}{e}=0.37$. Replacing the linguistic scale with the opposite, based on the condition that the project will be safer with less impact on the environment: $[0 ; 0.2]$ - "very good", $[0.2,0.37]$ - "good", [0.37; 0.63] - "satisfactory", [0.63; 1] - "bad".

Specific parameters are distributed on a scale that corresponds to the conditions of normalization, on the interval of effective values of the scale of partial indicators. Then, the corresponding indicators on the desirable scale are converted to the value of the field of definition of the Harrington function (Fig. 2).

Next, specific values are listed in numerical values in the range from -2 to +5 (Fig. 2). The choice of this gap on the scale of partial indicators is due to the fact that at these points the values of the scale of desirability are practically close to the limit, but they can still vary significantly depending on the values of the corresponding parameters. This gap can be called an effective range of practical values of comparison parameters.

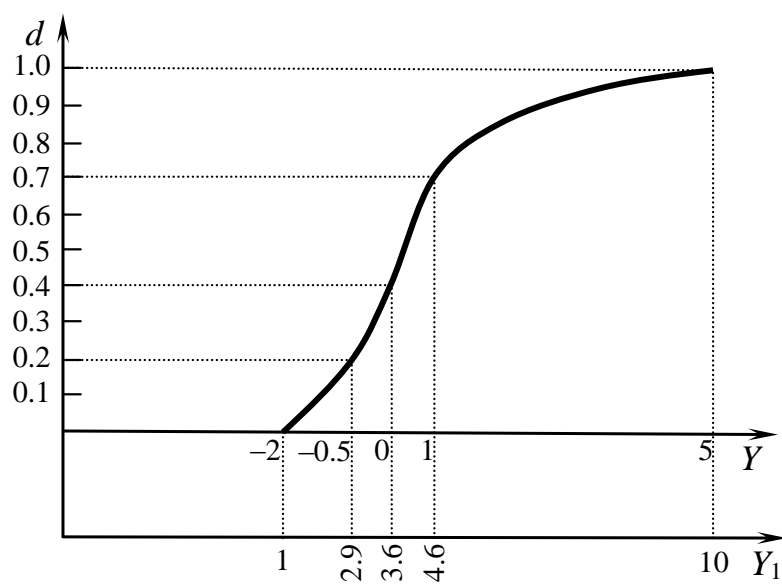

Fig. 2. Harrington Functions Graph 
Additionally, if from all values of this parameter the analyzed systems assign the "worst" mark " +5 ", and the "best" - "-2", then all others will be located between them, forming a scalable sequence of values. Converting them into partial indicators, we obtain a desirable coefficient for this parameter.

For this method, the interval $[1 ; 10]$ is taken as the definition area. Matching intervals are determined from the normalization condition (Table 2).

Table 2

Table of correspondence between the intervals of the definition of the Harrington function

\begin{tabular}{c|c|c|c}
\hline$d-$ scale of desirability & $\begin{array}{c}Y \text { - scale of partial } \\
\text { indicators ("old") }\end{array}$ & $\begin{array}{c}Y_{1} \text { - scale partial in- } \\
\text { dicators ("new") }\end{array}$ & Qualitative assessment \\
\hline$[0 ; 0.2]$ & {$[-2 ;-0.5]$} & {$[1 ; 2.9]$} & "very well" \\
\hline$[0.2 ; 0.37]$ & {$[-0.5 ; 0]$} & {$[2.9 ; 3.6]$} & "good" \\
\hline$[0.37 ; 0.63]$ & {$[0 ; 0.8]$} & {$[3.6 ; 4.6]$} & "satisfactorily" \\
\hline$[0.63 ; 1]$ & {$[0.8 ; 5]$} & {$[4.6 ; 10]$} & "not well" \\
\hline
\end{tabular}

The comparison of the values of the degree of influence for each parameter is estimated by the Harrington function according to the developed criteria. Each criterion is based on the practical experience of experts and experts obtained in the execution of similar projects.

For the natural environment we will accept the 4-spaced scale. This is due to the fact that, unlike the social sphere any activity will have an impact on the natural environment.

Zero effect will only be in the absence of technical activity or influence associated with natural variability. Therefore, in the future a multiplicative (multiplication) methodology of calculation is used for a comprehensive assessment of the impact on the natural environment.

Determination of spatial scale of influence. The determination of the spatial scale of impacts is made on the analysis of technical solutions, mathematical modeling, or on the basis of expert assessments and is presented in Table 3.

Table 3

Scale of estimation of spatial scale (area) of impacts

\begin{tabular}{|c|c|c|c|}
\hline Gradation & \multicolumn{2}{|c|}{ Spatial boundaries of influence (in sq. $\mathrm{km}$ or $\mathrm{km}$ ) } & $\begin{array}{c}\text { Scale } \\
\text { intervals }\end{array}$ \\
\hline Local impact & $\begin{array}{l}\text { Impact area is up to } 1 \\
\text { square } \mathrm{km}\end{array}$ & $\begin{array}{l}\text { impact at a distance of } 0,1 \mathrm{~km} \text { to the } \\
\text { linear object }\end{array}$ & $1 \ldots 2.9$ \\
\hline Limited impact & $\begin{array}{l}\text { impact area is up to } 10 \\
\text { square } \mathrm{km}\end{array}$ & $\begin{array}{l}\text { impact at a distance of } 1 \mathrm{~km} \text { from the } \\
\text { linear object }\end{array}$ & $2.9 \ldots 3.6$ \\
\hline $\begin{array}{l}\text { Local (territorial) } \\
\text { impact }\end{array}$ & $\begin{array}{c}\text { impact area is from } 10 \text { to } \\
100 \text { square } \mathrm{km}\end{array}$ & $\begin{array}{l}\text { impact at a distance of } 1 \text { to } 10 \mathrm{~km} \\
\text { from the linear object }\end{array}$ & $3.6 \ldots 4.6$ \\
\hline Regional impact & $\begin{array}{c}\text { impact area is over } 100 \\
\text { square } \mathrm{km}\end{array}$ & $\begin{array}{l}\text { impact at a distance of more than } 10 \\
\mathrm{~km} \text { from a linear object }\end{array}$ & $4.6 \ldots 10$ \\
\hline
\end{tabular}

Local impacts are the impacts that affect on the components of the natural environment, are limited by the territory (water area) of the direct placement of the object or slightly exceed it by area (up to $1 \mathrm{sq}$. km). Influence on elementary natural and territorial complexes on the land at the level of the tracts

Limited impacts are the impacts that affect on the components of the natural environment on the territory (water area) up to 10 square $\mathrm{km}$. (Influence on natural and territorial complexes on land at the level of groups of tracts or terrain).

Local (territorial) impacts are the impacts on the components of the natural environment on the territory (water area) up to 100 square $\mathrm{km}$. Influence on natural and terrestrial complexes on land at the level of the landscape).

Regional impacts are the impacts on the components of the natural environment on a regional scale in the territory (waters) of more than 100 square $\mathrm{km}$. (Influence on natural and territorial complexes on land at the level of landscape districts or region). 
Definition of a temporary scale of influence. Temporary scale of impacts on individual components of the natural environment is determined on the basis of technical analysis, analytical (model) or expert estimates, and presented in Table 4.

Table 4

Scale of temporary impact assessment

\begin{tabular}{c|c|c}
\hline Gradations & Temporal scope of impact & Scale intervals \\
\hline Short-term impact & The impact is observed up to 3 months & $1 \ldots 2.9$ \\
\hline Impact of medium duration & impact observed from 3 months to 1 year & $2.9 \ldots 3.6$ \\
\hline Long stay under impact & The impact observed from 1 to 3 years & $3.6 \ldots 4.6$ \\
\hline Long-term (permanent) effect & The impact observed from 3 to 5 years or more & $4.6 \ldots 10$ \\
\hline
\end{tabular}

Short-term impact is an effect that is observed for a limited period of time (for example, during construction, drilling or decommissioning), but usually ceases after the completion of a work operation, the duration does not exceed one season ( 3 months is allowed).

The impact of medium duration is the effect that manifests itself from one season ( 3 months) to 1 year.

Long stay under impact is the effect observed over a long period of time (more than 1 year but less than 3 years) and usually covers the period of construction of the projected object.

Long-term (permanent) impact is the effect observed from 3 to 5 years or more (for example, noise from operation), which may be more frequent or recurrent (for example, as a result of annual maintenance work). Mainly refers to the period when the design power is reached.

Determining the magnitude of the intensity of the impact. The scale of intensity is determined on the basis of a number of environmental assessments, as well as expert opinions, and is discussed in Table 5. Involvement of expert assessments is usually required when there are no criteria for assessing the intensity of influence, for example, to assess individual emergencies.

Table 5

Scale of impact intensity

\begin{tabular}{c|c|c}
\hline Scale & Description of the intensity of the impact & $\begin{array}{c}\text { Scale } \\
\text { intervals }\end{array}$ \\
\hline Little impact & Changes in the environment do not exceed the existing limits of natural \\
variability & $1 \ldots 2.9$ \\
\hline Weak impact & $\begin{array}{c}\text { Changes in the natural environment exceed the limits of natural variability, } \\
\text { the natural environment is completely self-healing. }\end{array}$ & $2.9 \ldots 3.6$ \\
\hline $\begin{array}{c}\text { Moderate } \\
\text { impact }\end{array}$ & $\begin{array}{c}\text { Changes in the natural environment, exceeding the limits of natural } \\
\text { variability, lead to the violation of certain components of the environment. } \\
\text { The natural environment retains the ability to self-healing. }\end{array}$ & $3.6 \ldots 4.6$ \\
\hline Strong impact & $\begin{array}{c}\text { Changes in the natural environment result in significant damage to the } \\
\text { components of the environment and / or the ecosystem. Separate } \\
\text { components of the natural environment lose their ability to self-healing (this } \\
\text { statement does not apply to atmospheric air). }\end{array}$ & $4.6 \ldots 10$ \\
\hline
\end{tabular}

For the air environment, the criteria are chosen based on the experience of calculating greenhouse gas emissions when preparing EIAs.

For aquatic environment are using hydrodynamic simulations, tutorials, and expert methods.

The geological environment is considered on the basis of maps of dangerous processes and expert assessments.

For groundwater, the criteria are determined on the basis of the simulation of the distribution of pollutants, expert way or on the basis of analogues.

Criteria for soil and land are considered on the basis of technical decisions, special studies or expertise.

The components of the evaluation required for this project can be summarized in a summary table and enclosed with the main project documentation. 
Integrated assessment of the impact on individual components of the natural environment from various sources of impacts. Significance of impact is essentially a complex (integral) estimate. Comprehensive evaluation is a multi-stage process. Determination of significance of impact is carried out in several stages.

Stage 1. To determine the complex impact on individual components of the environment, it is necessary to use tables with the criteria of influence (Tables 3, 4 and 5).

Complex score is determined by the formula:

$$
Q_{\text {complex }}^{i}=Q_{i}^{t} \cdot Q_{i}^{s} \cdot Q_{i}^{f},
$$

where $Q_{\text {complex }}^{i}$ - integrated assessment score for the considered impact;

$Q_{i}^{t}$ - score of temporary impact on the $i$-th component of the environment;

$Q_{i}^{s}$ - spot impact score on the $i$-th component of the natural environment;

$Q_{i}^{f}$ - score of intensity of influence on the $i$-th component of the natural environment.

Stage 2 . The category of significance is determined by the interval of values, depending on the score obtained in the calculation of the complex assessment, as shown in Table 6.

Table 6

Categories of significance of impacts

\begin{tabular}{|c|c|c|c|c|}
\hline \multicolumn{3}{|c|}{ Impact categories, scale intervals } & \multicolumn{2}{|c|}{ Categories of significance } \\
\hline Spatial scale & $\begin{array}{c}\text { Temporary } \\
\text { scale }\end{array}$ & Intensity of impact & Interval & Significance \\
\hline $\begin{array}{l}\text { Local } \\
1 \ldots 2.9\end{array}$ & $\begin{array}{c}\text { Short-Temporary } \\
\quad 1 \ldots 2.9\end{array}$ & $\begin{array}{l}\text { Insignificant } \\
\quad 1 \ldots 2.9\end{array}$ & \multirow[t]{2}{*}{$1 \ldots 25$} & \multirow[t]{2}{*}{$\begin{array}{l}\text { The impact of low } \\
\text { significance }\end{array}$} \\
\hline \multirow{2}{*}{$\begin{array}{c}\text { limited } \\
2.9 \ldots 3.6 \\
\end{array}$} & \multirow{2}{*}{$\begin{array}{c}\text { Average duration } \\
2.9 \ldots 3.6 \\
\end{array}$} & \multirow{2}{*}{$\begin{array}{c}\text { Weak } \\
2.9 \ldots 3.6 \\
\end{array}$} & & \\
\hline & & & \multirow{2}{*}{$25 \ldots 100$} & \multirow{2}{*}{$\begin{array}{c}\text { Impact } \\
\text { of average im- } \\
\text { portance }\end{array}$} \\
\hline \multirow{2}{*}{$\begin{array}{c}\text { Local } \\
3.6 \ldots . .6 .6\end{array}$} & \multirow{2}{*}{$\begin{array}{c}\text { Long } \\
3.6 \ldots 4.6\end{array}$} & \multirow{2}{*}{$\begin{array}{l}\text { Medium } \\
3.6 \ldots 4.6\end{array}$} & & \\
\hline & & & \multirow{2}{*}{$100 \ldots 1000$} & \multirow{2}{*}{$\begin{array}{l}\text { Impact } \\
\text { of high signifi- } \\
\text { cance }\end{array}$} \\
\hline $\begin{array}{c}\text { Regional } \\
4.6 \ldots 10\end{array}$ & $\begin{array}{l}\text { Many years } \\
4.6 \ldots 10\end{array}$ & $\begin{array}{l}\text { High } \\
4.6 \ldots 10\end{array}$ & & \\
\hline
\end{tabular}

The categories of significance are the same for different components of the natural environment and can already be comparable to determine the component of the environment that will experience the most severe effects.

For presentation of results in this EIA, the three categories of impact significance are considered low, medium and significant.

Impact of low significance occurs when the effects are tested, but the magnitude of the impact is rather low and is within acceptable limits.

The medium impact can have a wide range, ranging from the threshold below which the effect is low, to the level, almost violates the legal limit. As far as possible, it is necessary to show the fact of reducing of the medium impact significance.

The impact of high significance occurs when the permissible limits are exceeded or when there is a large-scale impact, especially on valuable / sensitive resources.

Categories of significance are determined for the following environmental components:

- impact on soils and subsoil;

- impact on surface, ground and underground waters;

- impact on the quality of atmospheric air;

- impact on various physical processes (flood, erosion, etc.);

- impact on biological objects of the sea and land, as well as species endangered; 
- impact on wildlife, rural and forestry;

- impact on landscapes, landscapes and nature reserves.

And also to assess the physical factors of influence: noise and electromagnetic effects, vibration and power fields and background radiation.

To obtain a category of the significance of the impact, first, for each component of the environment, we determine the average score of the comprehensive impact assessment (for example, the project "Lakes Reclamation Project in the Odessa-Sortuvalna of Odessa Railway") [7, 9].

In this project, the resulting significance can be defined as "low", since two types of influence have a low significance of impact, one is a medium, and a comprehensive assessment of the source of impact "Education and setting of suspensions" is 27.6. Low limit of the interval of medium importance $(25 \ldots 100)$ equals 25 . When some components change, the estimate is reduced to a low significance of impact [10].

If the significance of the impact determined for a particular component of the environment (atmospheric air, fauna, etc.) is the only one, it is used directly to assess the resulting significance of the impact.

In practice, one component of the natural environment can be given a variety of effects of many sources, so to determine the significance of the impact is used a resulting assessment of the significance of a specific component of the environment [11]. Based on the results of the identified levels of significance of influence, an expert can provide an integrated assessment of the impact on a particular component of the environment. An example of determining the resultant significance of the impact and integral assessment is presented in Tables 6 and 7.

Table 7

An example of the calculation of the significance of the environmental impact

\begin{tabular}{|c|c|c|c|c|c|c|}
\hline $\begin{array}{l}\text { Environmental } \\
\text { components }\end{array}$ & $\begin{array}{l}\text { Source and } \\
\text { type of } \\
\text { impact }\end{array}$ & Spatial scale & $\begin{array}{l}\text { Temporal } \\
\text { Scale }\end{array}$ & $\begin{array}{c}\text { Intensity of } \\
\text { impact }\end{array}$ & $\begin{array}{c}\text { Significance } \\
\text { of impact } \\
\text { Comprehens } \\
\text { ive } \\
\text { evaluation }\end{array}$ & $\begin{array}{l}\text { Categories } \\
\text { of } \\
\text { significance } \\
\text { of influence }\end{array}$ \\
\hline \multirow{5}{*}{$\begin{array}{l}\text { Activity of } \\
\text { karst and } \\
\text { suffusion } \\
\text { processes }\end{array}$} & $\begin{array}{l}\text { Violation of } \\
\text { bottom } \\
\text { sediments } \\
\text { and in } \\
\text { cleaning the } \\
\text { bottom of } \\
\text { lakes }\end{array}$ & $\begin{array}{c}\text { Local } \\
1 \ldots 2.9 \\
(2)\end{array}$ & $\begin{array}{c}\text { Long term } \\
3.6 \ldots 4.6 \\
(4.4)\end{array}$ & $\begin{array}{c}\text { Moderate } \\
3.6 \ldots 4.6 \\
\quad(4.4)\end{array}$ & 38.8 & Medium \\
\hline & $\begin{array}{c}\text { Destruction } \\
\text { of vegetation } \\
\text { at dumping } \\
\text { of building } \\
\text { rock }\end{array}$ & $\begin{array}{l}\text { Local } \\
1 \ldots 2.9 \\
(1.3)\end{array}$ & $\begin{array}{c}\text { Short term } \\
1 \ldots 2.9 \\
(1.3)\end{array}$ & $\begin{array}{c}\text { Weak } \\
2.9 \ldots 3.6 \\
(3.2)\end{array}$ & 5.4 & Low \\
\hline & $\begin{array}{l}\text { Formation of } \\
\text { suspensions }\end{array}$ & $\begin{array}{c}\text { Local } \\
1 \ldots 2.9 \\
(2.2)\end{array}$ & $\begin{array}{c}\text { Average } \\
\text { duration } \\
2.9 \ldots 3.6 \\
(3.3)\end{array}$ & $\begin{array}{c}\text { Moderate } \\
3.6 \ldots 4.6 \\
(3.8)\end{array}$ & 27.6 & Medium \\
\hline & $\begin{array}{c}\text { Elimination } \\
\text { of a buffer } \\
\text { lake }\end{array}$ & $\begin{array}{c}\text { Local } \\
1 \ldots 2.9 \\
(1.1)\end{array}$ & $\begin{array}{c}\text { Average } \\
\text { duration } \\
2.9 \ldots 3.6 \\
(3.2)\end{array}$ & $\begin{array}{c}\text { Weak } \\
2.9 \ldots 3.6 \\
(3.0)\end{array}$ & 10.6 & Low \\
\hline & \multicolumn{3}{|c|}{ The resulting impact significance } & \multicolumn{3}{|c|}{ Low significance } \\
\hline
\end{tabular}

Results. So, the presented technique is aimed at generalizing Ukrainian and international experience with EIAs and specifying evaluation criteria. 
The development methodological approaches understood by Ukrainian experts and based on regulatory requirements and international requirements on which references are used, were used.

Conclusions. The developed and proposed methodological aspects of the environmental impact assessment should be used to develop the final EIA.

The comprehensive impact assessment for any components of the natural environment is described. The mechanism for determining the significance of influence is proposed.

The developed method of impact assessment allows:

- to conduct an assessment of the impact on the natural environment under the influence of various sources;

- to determine the significance of environmental impact.

The proposed criteria allow making concrete conclusions on the assessment of the impact on each environment, which is of prime importance in conducting environmental expertise.

The proposed methodology of EIA allows, based on the results of the impact assessment, expressed in points, to move to the assessment of alternative options for project implementation in scores.

The resulting impact significance scores for each component of the environment can make for the total significance of the impact of each alternative project.

The most attractive from the ecological point of view should be considered an option to implement a project with the lowest significance of the impact.

\section{Література}

1. Всеукраїнський науковий центр екологічних досліджень та аудиту. Закон України про екологічну експертизу. URL: http://www.kp-limit.kharkov.ua/zakonodatelstvo.php?loc=ua (дата звернення: 15.12.2017).

2. Lee N., Colley R. Reviewing the Quality of Environmental Statements. Occasional Paper Number 24. EIA Centre. University of Manchester. 1990, 36 p.

3. Sadler, B. Final Report of the International Study of the Effectiveness of Environmental Assessment. CEAA and IAIA. Canada. 1996. $248 \mathrm{c}$.

4. Методические указания по проведению оценки воздействия хозяйственной деятельности на окружающую среду. Астана, 2009. URL: https://online.zakon.kz/Document/?doc_id= 30935945\#pos=0;0 (дата звернення: 15.12.2017).

5. Олех Т.М. Руденко С.В, Гогунский В.Д. Оценка эффективности экологических проектов. Bocm.Европ. журнал передовых технологий. 2013. № 1/10(61). С. 79-82.

6. Руденко С.В., Олех Т.М., Гогунский В.Д. Модель обобщенной оценки воздействия на окружающую среду в проектах. Управління розвитком складних систем. 2013. № 15. С. 53-60.

7. Руденко С.В., Колесникова Е.В., Олех Т.М. Анализ результатов реализации техникоэкономической природоохранной региональной программы. Проблеми техніки. 2013. № 2. C. $161-169$.

8. Олех Т.М., Колесникова Е.В., Руденко С.В. Экологическая оценка проектов. Праиі Одеського політехнічного університету. 2013. № 2(41). С. 276-282.

9. Олех Т.М., Гогунський В.Д. Гармонизация подходов к оценке воздействия на окружающую среду. Моделирование в прикладных научных исследованиях: Материалы XXV семинара. 2017. C. 47-48.

10. Bochkovskyi A., Sapozhnikova N., Gogunskii V. Legal and organizational issues of improving the labor protection and industrial safety level at Ukrainian enterprises. Scientific Bulletin of National Mining University. 2017. № 5(161). P. 100-108.

11. Development of the model of interaction among the project, team of project and project environment in project system / O. Kolesnikov et al. Eastern-European Journal of Enterprise Technologies. 2016. № 5/9(83). C. 20-26.

\section{References}

1. All-Ukrainian Scientific Center for Environmental Research and Audit. The Law of Ukraine on Environmental Expertise. kp-limit.kharkov.ua Retrieved from http://www.kp-limit.kharkov.ua/ zakonodatelstvo.php?loc=ua. 
2. Lee N. \& Colley R. (1990) Reviewing the Quality of Environmental Statements. Occasional Paper Number 24. EIA Centre. University of Manchester.

3. Sadler B. (1996) Final Report of the International Study of the Effectiveness of Environmental Assessment. CEAA and IAIA. Canada.

4. Methodical instructions for carrying out the assessment of the impact of economic activity on the environment. (2009). Astana. online.zakon.kz Retrieved from https://online.zakon.kz/Document/?doc_id= $30935945 \#$ pos $=0$; 0 .

5. Olekh T.M., Rudenko S.V. \& Gogunskii V.D. (2013). Evaluating the effectiveness of environmental projects. Eastern-European Journal of Enterprise Technologies, 1/10, 61, 79-82.

6. Rudenko S.V., Olekh T.M., \& Gogunskii V.D. (2013). Model of a generalized environmental impact assessment in projects. Management of Development of Complex Systems, 15, 53-60.

7. Rudenko S.V., Kolesnikova E.V., \& Olekh T.M. (2013). Analysis of the results of the implementation of the technical and economic nature protection regional program. Problems of technology, 2, 161-169.

8. Olekh T.M., Kolesnikova E.V., \& Rudenko S.V. (2013). Environmental assessment of projects. Proceedings of Odessa Polytechnic University, 2, 41, 276-282.

9. Olehk T.M., \& Gogunskii V.D. (2017). Harmonization of Approaches to Environmental Impact Assessment. Modeling in Applied Scientific Researches: materials of the XXV seminar, 47-48.

10. Bochkovskyi A., Sapozhnikova N., \& Gogunskii V. (2017). Legal and organizational issues of improving the labor protection and industrial safety level at Ukrainian enterprises. Scientific Bulletin of $\mathrm{Na}$ tional Mining University, 5, 161, 100-108.

11. Kolesnikov O., Gogunskii V., Kolesnikova K., Lukianov D., \& Olekh T. (2016). Development of the model of interaction among the project, team of project and project environment in project system. Eastern-European Journal of Enterprise Technologies, 5/9, 83, 20-26.

Становський Олександр Леонідович; Olexandr Stanovskiy, ORCID: https://orcid.org/0000-0002-0360-1173

Прокопович Ігор Валентинович; Prokopovich Ihor, ORCID: https://orcid.org/0000-0002-8059-6507

Олех Георгій Сергійович; Olekh Heorhii, ORCID: https://orcid.org/0000-0002-7033-8504

Колеснікова Катерина Вікторівна; Kolesnikova Kateryna, ORCID: http://orcid.org/0000-0002-9160-5982

Сорокіна Людміла Iгорівна; Sorokina Liudmyla, ORCID: https://orcid.org/0000-0002-1840-6944 